\title{
Food habit of the endangered yellow-spotted newt Neurergus microspilotus (Caudata, Salamandridae) in Kavat Stream, western Iran
}

\author{
Hossein Farasat and Mozafar Sharifi ${ }^{*}$
}

\begin{abstract}
Background: Diversity and abundance of macroinvertebrate fauna were simultaneously determined in selected benthic samples and in regurgitated stomach contents in Neurergus microspilotus in Kavat Stream (western Iran) during April and May 2012. The aim of this study was to determine the degree of reliance of this species to benthic macroinvertebrates during their reproductive season in aquatic habitat.

Results: Twenty-one taxa of macroinvertebrates were identified in the benthic samples while 19 taxa were presented in the regurgitated stomach contents. Data obtained from benthic samples showed that the most abundant macroinvertebrate groups included Lumbricidae (27.2\%), Mycetophilidae (20.06\%), Gammaridae (12.19\%), and Plananariidae (9.3\%). Data obtained from 45 stomach contents indicated that on average the highest importance values combining number, frequency, and volume for prey categories consumed included Mycetophilidae (14.03\%), Baetidae (13.68\%), Corbiculidae (12.57\%), Gammaridae (10.8\%), and Lumbricidae (9.34\%). N. microspilotus also consumed small stones, plant materials, and their own eggs (0.91\%). The analysis of selectivity in feeding using Ivlev's index showed that the prey taxa that appeared to be preferred $\left(E_{i}>0.5\right)$ were generally rare in the environment.
\end{abstract}

Conclusions: Comparison between benthic macroinvertebrates and those taken by the newt demonstrates that although high similarity (Sorenson index of 78.94\%) exists between the two communities, the dominance of the items taken by N. microspilotus (Simpson index $=0.32$ ) is higher than that of the benthic community (Simpson index $=0.20$ ) indicating that the newts rely on fewer number of species with higher proportion of individual prey items. Feeding habits of $45 \mathrm{~N}$. microspilotus have shown that the newts rely extensively on Mycetophilidae, Baetidae, Corbiculidae, Gammaridae, and Lumbricidae as important food items for N. microspilotus.

Keywords: Neurergus microspilotus; Feeding habits; Stomach content; Benthic macroinvertebrates; Kavat Stream

\section{Background}

Relatively few Caudata occur in Iran. These include seven species of the genera Triturus, Paradactylodon, Neurergus, and Salamandra (Baloutch and Kami 1995). Newts of the genus Neurergus have a relatively wide geographic distribution, ranging from western Iran (Zagros Mountains) and extending to Iraq and southern Turkey (Baloutch and Kami 1995). The yellow-spotted newt occupies an assortment of aquatic microhabitats during the breeding season. Visual determination of substrate texture in Kavat Stream

\footnotetext{
* Correspondence: sharifimozafar2012@gmail.com

Department of Biology, Faculty of Science, Center for Environmental Studies, Razi University, Baghabrisham, 6714967346 Kermanshah, Iran
}

indicated that this newt tends to occupy substrates containing gravels and pebbles (Sharifi and Assadian 2004). Two species of the genus Neurergus ( $N$. kaiseri and $N$. microspilotus) are listed as critically endangered by the IUCN criteria (IUCN Red List of Threatened Species. Available from http://www.iucnredlist.org). This species is listed as critically endangered because its area of occupancy is less than $10 \mathrm{~km}^{2}$, and there is a continuing decline in the extent and quality of its stream habitat and in the number of subpopulations and individuals because of habitat degradation, drought, and over collection of animals for both national and international pet trade. Habitat loss through divergence of streams for irrigation is probably the most important factor that 
threatens the species in its Iranian range (Sharifi and Assadian 2004). Investigation made by Sharifi and Assadian (2004) on N. microspilotus have confirmed that this newt occurs in several highland streams in the mid-Zagros mountains but is highly vulnerable to the rapid changes occurring in their aquatic and terrestrial habitats.

There is no available information regarding feeding habits of $N$. microspilotus in Iran, Iraq, or possibly in southern Turkey. Among closely related species in southern Turkey, it is evident that the Lycian salamander (Mertensiella luschani) chiefly preys upon aquatic insects. Serdar and Rizvan (2004) have shown that this species preys mostly on aquatic Coleoptera. In a similar study based on the stomach contents in Salamander leurognathus (Martof and Scott 1957), it was shown that more that $70 \%$ of food items in this species consist of Ephemeroptera and Trichoptera. Maerz et al. (2006) have shown that although feeding habits of salamanders differ at different times of the year and in various habitat types, however, Oligochaeta, Coleoptera, and Isopoda are the most important food items of this animal. Feeding habits have also been reported in different species of amphibian including Bufo melanostictus by Sreelatha et al. (1990) and Pleurodema diplolistris by Santos et al. (2003). These studies have shown that although frog diet consisted of a wide variety of arthropods including Diptera and Coleoptera, the aquatic forms did not contribute much to their diet. Other studies have demonstrated that the prey items identified in the diets of different species of Anura shows that these species are generalist and opportunistic predators whose diet is most strongly influenced by prey availability (Toshiaki 2002; Kerim and Ahmet 2007; Caldart et al. 2012.

The present investigation aims to determine variation in diversity and abundance of benthic macroinvertebrates. This study also intended to show food preference and feeding habits of $N$. microspilotus which may reflect the availability of prey items in Kavat Stream.

\section{Methods}

\section{The species}

Three species of the genus Neurergus have been reported to occur on the Iranian plateau, in Northern, Central, and southern parts of the Zagros Mountains. These include $N$. crocatus Cope 1862 from Northwestern Iran, Northeastern Iraq, and Southeastern Turkey; $N$. microspilotus (Nesterov 1916) from Western Iran and Iraq; and N. kaiseri Schmidt 1952 from the Southern Zagros Mountains in Lorestan and Khusistan provinces in southern Iran. Previous studies on this genus are scant and mainly limited to original descriptions and anecdotal explanations. However, Schmidtler and Schmidtler (1975) studied different populations of Neurergus and confirmed the presence of three allopathic species belonging to this genus from Iran and a fourth species in Turkey.

\section{Study area}

Kavat Stream $\left(34^{\circ} 52^{\prime} \mathrm{N}, 46^{\circ} 30^{\prime} \mathrm{E}\right)$ is a known habitat for $N$. microspilotus with the highest visual count for this species in its Iranian range (Sharifi and Assadian 2004). It is a relatively long stream with a mean annual discharge of $625.7 \mathrm{l} / \mathrm{s}$. This site is located in an area of relatively less disturbed open woodland and low-intensity agriculture practice and an established horticulture along the stream (Figure 1). The horticultural activities rely on an extensive system of terracing supported by stone walls and also diversion of water from the main stream. A large and permanent karst spring feeds the stream. At very steep banks of the stream, there are outcrops of sedimentary rocks with high porosity that provide a valuable area for foraging and hiding of the newts. The recorded temperatures of water during the study period range from $11^{\circ} \mathrm{C}$ to $14^{\circ} \mathrm{C}$. As an indicative of cold climate appropriate for the yellow-spotted newts, various species of mosses are present as a part of benthic, epipelic, and epilithic vegetation cover. Terrestrial habitats around streams where $N$. microspilotus has been observed include diverse community types known as oak-pistachio open woodlands dominated by Quercus brantii and Pistachia spp (Sharifi and Vaissi 2014). This open woodland grows on various soil types including deep sandy loam soils at the bottom of the valleys or gravelly soils at the slopes of steep valleys. In some parts, the above stream vegetation along Kavat Stream has been replaced by orchard trees.

\section{Benthic macroinvertebrate fauna}

Sampling from benthic macroinvertebrates was performed on 20 April and 15 May 2012. Benthic macroinvertebrate fauna were collected by kick sampling in the fast-flowing waters in Kavat Stream. This sampling involved shuffling through the substrate within a quadrate $(0.4 \times 0.4 \mathrm{~m})$ against another quadrate with the same size which had a mesh bag and located perpendicular to the benthos in the opposite direction to the flow of the stream about $1 \mathrm{~m}$ from the water's edge. All invertebrates were killed in the field using small quantities of $40 \%$ formaldehyde and later preserved in 96\% ethanol for further examination. Further analyses carried out in the laboratory included counting and sorting the specimens under suitable magnifications ( $x 7$ to 40 ). The benthic macroinvertebrates were identified using manuals of Bouchard (2004), Thyssen (2010), and Parker and Consulting (2012). Shannon-Wiener index of general diversity $\left(H=-\sum\left(n_{\mathrm{i}} / N\right) \log \left(n_{\mathrm{i}} / N\right)\right)$ was used to express the diversity of benthic macroinvertebrates. Simpson index of dominance $\left(c=\sum\left(n_{\mathrm{i}} / N\right)^{2}\right)$ was used to determine how relative importance of different species is distributed 


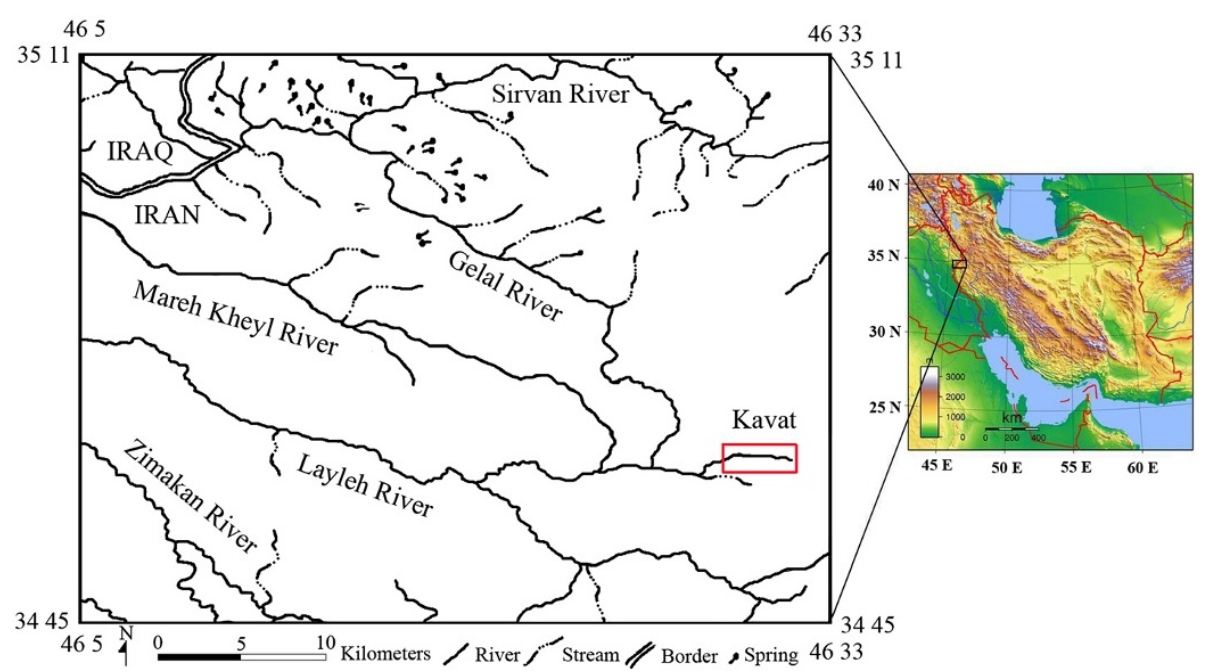

Figure 1 Geographic position of Kavat Stream in the mid-Zagros range in western Iran.

within the community. Sorenson index of similarity $\left(I_{\mathrm{S}}=2 \mathrm{C} / \mathrm{A}+\mathrm{B}\right)$ was also used in order to compare degrees of similarity between benthic macroinvertebrates and those taken by the yellow-spotted newt.

\section{Stomach content}

N. microspilotus used in the present study (45 individuals, 22 in 20 April and 23 in 15 May 2012) were all caught at daytime. The newts were captured by hand. Gastric lavage was used to extract the stomach contents of the live animals. A tube was inserted through the newt's mouth into its stomach, and the stomach was pumped by a $60-\mathrm{ml}$ syringe full of water until the newt regurgitates the stomach contents. These food items were filtered from the water and preserved in $96 \%$ ethanol solution for later identification and quantification. Although it may not be a pleasant experience for the newts, the survival rate of $N$. microspilotus that has gone through the gastric lavage was $100 \%$ in the present study. The permit for collecting $N$. microspilotus for the present study was issued by the Kermanshah Department of Environment. In extracting the stomach contents using gastric lavage, we firmly determined to avoid any casualty to the specimens. The newts were kept in small $(30 \times 30 \mathrm{~cm})$ pools by putting up several stones at the sampling site for approximately 2 hours to see if this experiment causes any visible side effect and then released. This experiment showed no mortality.

Prey categories consumed by $N$. microspilotus were analyzed in terms of the number, occurrence, and volume of each prey category. The volume of each prey was estimated by the formula of an ovoid spheroid, proposed by Dunham (1983), $V=4 / 3 \pi(L / 2)(W / 2)$, where $L$ corresponds to the greatest length and $W$ to the largest width of the prey. An index of importance $\left(I_{\mathrm{x}}\right)$ was calculated for each prey category by the formula proposed by Caldart et al. (2012) by summing the percentage of occurrence and the numeric and volumetric percentages of each prey in the diet and dividing it by 3 . The sufficiency of the sample to assess in feeding habit was evaluated by an accumulation curve of prey categories, using EstimateS 9.1 software with 1,000 random additions (Colwell 2013).

Ivlev's $E_{\mathrm{i}}$ index (Ivlev 1961), $E_{\mathrm{i}}=\left(n_{\mathrm{i}}-r_{\mathrm{i}}\right) /\left(n_{\mathrm{i}}+r_{i}\right)$, was used to estimate selectivity in feeding behavior in $N$. microspilotus. In this equation, $n_{\mathrm{i}}$ represents the proportion of prey taxa $i$ in the stomach contents and $r_{\mathrm{i}}$ represents the proportion in the benthic macroinvertebrate community. $E_{\mathrm{i}}$ can vary between -1 and 1 . In this study, the thresholds of $E_{i}=0.5$ (Cogalniceanu et al. 1998) are used to determine the selectivity in feeding behavior. The thresholds of $E_{\mathrm{i}}>0.5$ are considered preferred, and those with $E_{\mathrm{i}}<0.5$ are considered avoided food items $i$. To evaluate the correlations between relative abundance of benthic macroinvertebrate in Kavat Stream and regurgitated stomach contents, Pearson's correlations were performed.

\section{Statistical analysis}

In order to determine correlation and frequency of species in sampled quadrates and the stomach contents, correlation coefficients were determined between relative abundance of various taxa in sampled quadrats and the newt regurgitates using Microsoft Office Excel 2007 and SPSS statistical package (version 15, SPSS Inc., Chicago, IL, USA).

\section{Results}

A check list demonstrating the phyla, classes, families, and genus/species of the benthic macroinvertebrate fauna identified in Kavat Stream is presented in Table 1. A total 
Table $1 \mathrm{~A}$ checklist of the benthic invertebrates sampled

\begin{tabular}{|c|c|c|c|c|c|}
\hline Phylum & Class & Order & Family & Genus & Species \\
\hline \multirow[t]{2}{*}{ Annelida } & Oligochaeta & Opisthopora & Lumbricidae & Aporrectodea & rosea \\
\hline & & & & Eiseniella & tetraedra \\
\hline \multirow[t]{15}{*}{ Arthropoda } & Malacostraca & Amphipoda & Gammaridae & Gammarus & daiberi \\
\hline & Insecta & Diptera & Mycetophilidae & Rhymosia & sp. \\
\hline & & & Cecidomyiidae & Parepidosis & ulmicorticis \\
\hline & & & Tipulidae & Nephrotoma & sp. \\
\hline & & & Chamaemyiidae & cecidomyia & sp. \\
\hline & & Hemiptera & Veliidae & Velia & sp. \\
\hline & & & & Velia & hereroptera \\
\hline & & Coleoptera & Dytiscidae & Laccophilus & sp. \\
\hline & & & Elmidae & Narpus & sp. \\
\hline & & Ephemeroptera & Baetidae & Baetis & sp. \\
\hline & & & Ephemeridae & Ephemerella & doris \\
\hline & & & Heptageniidae & Maccaffertium & sp. \\
\hline & & Trichoptera & Hydropsychidae & Cheumatopsyche & sp. \\
\hline & & Hymenoptera & Formicidae & Formica & sp. \\
\hline & & Odonata & Cordulegastridae & Cordulegaster & sp. \\
\hline \multirow[t]{3}{*}{ Mollusca } & Gastropoda & Hygrophila & Planorbidae & Planorbis & planorbis \\
\hline & & Mesogastropoda & Bithynidae & Bithynia & tentaculata \\
\hline & Bivalvia & Veneroida & Corbiculidae & Corbicula & fluminea \\
\hline Platyhelminthes & Turbellaria & Tricladida & Planariidae & Polycelis & felina \\
\hline
\end{tabular}

of 21 taxa of benthic invertebrate fauna belonging to four phyla (Annelida, Arthropoda, Mollusca, and Platyhelminthes), six classes (Oligochaeta, Malacostraca, Insecta, Gastropoda, Bivalvia, and Turbellaria), 13 orders, and 19 families were identified. Table 2 shows the total number of families, species, and percent composition of the benthic macroinvertebrate fauna in the study area. The number and relative frequency of macroinvertebrate species sampled during April and May in Kavat Stream are shown in Table 3. The most abundant families included Lumbricidae (27.2\%), Mycetophilidae (20.06\%), Gammaridae (12.19\%), Plananariidae (9.3\%), Heptageniidae (6.92\%), Hydropsychidae (6.39\%), and Baetidae (6.16\%). These families encompass about $88.22 \%$ of the total number of benthic macroinvertebrates and the remaining (11.78\%) includes species of Formicidae
(Formica sp), Planorbidae (Planorbis planorbis), Bithyniidae (Bithynia tentaculata), Corbiculidae (Corbicula fluminea), and Planariidae (Polycelis feline) (Table 3).

Four categories of the stomach contents were identified in the yellow-spotted newt sampled in the Kavat Stream. These include prey of animal type, plant materials, amphibian eggs, and inorganic particles including small gravels. $N$. microspilotus sampled in the present study consumed a total number of 489 preys belonging to 19 prey taxa from which six taxa were common in both sampling occasions. From the stomach contents of the newts captured in the April, 188 items were identified. These items belong to nine orders and 11 species. Similar values for the stomach contents sampled in May included 301 individuals belonging to 12 orders and 14 species. The newts that had empty stomachs

Table 2 Number of classes, orders, families, and species in each phylum of the benthic organisms

\begin{tabular}{llllll}
\hline Phylum & Classes & Orders & Families & Species \\
\hline Annelida & 1 & 1 & 1 & 14 & 2 \\
Arthropoda & 2 & 8 & 3.49 \\
Mollusca & 2 & 3 & 3 & 15 \\
Platyhelminthes & 1 & 1 & 1 & 3 & 1.42 \\
Total & 6 & 13 & 19 & 21 \\
\hline
\end{tabular}


Table 3 Electivity values of prey categories consumed by N. microspilotus

\begin{tabular}{|c|c|c|c|c|c|}
\hline \multirow{2}{*}{ Prey category } & \multicolumn{2}{|l|}{ Diet } & \multicolumn{2}{|c|}{ Macroinvertebrate } & \multirow{2}{*}{$\begin{array}{l}\text { Electivity } \\
\left(E_{\mathrm{i}}\right)\end{array}$} \\
\hline & $N$ & $\% N$ & $N$ & $\% N$ & \\
\hline Annelida-Lumbricidae & 22 & 4.5 & 1316 & 27.20 & $-0.72^{b}$ \\
\hline Amphipoda-Gammaridae & 48 & 9.82 & 590 & 12.19 & -0.11 \\
\hline Diptera-Mycetophilidae & 120 & 24.54 & 971 & 20.06 & 0.10 \\
\hline Diptera-Cecidomyiidae & 13 & 2.66 & 85 & 1.76 & 0.20 \\
\hline Hemiptera-Veliidae & 4 & 0.82 & 51 & 1.05 & -0.13 \\
\hline Coleoptera-Dytiscidae & 5 & 1.02 & 93 & 1.92 & -0.31 \\
\hline Coleoptera-Elmidae & 1 & 0.2 & 7 & 0.14 & 0.17 \\
\hline Ephemeroptera-Baetidae & 96 & 19.63 & 289 & 6.16 & $0.52^{\mathrm{a}}$ \\
\hline Ephemeroptera-Heptageniidae & 9 & 1.84 & 335 & 6.92 & $-0.58^{b}$ \\
\hline Trichoptera-Hydropsychidae & 25 & 5.11 & 309 & 6.39 & -0.11 \\
\hline Hymenoptera-Formicidae & 3 & 0.61 & 13 & 0.27 & 0.39 \\
\hline Mesogastropoda-Bithynidae & 9 & 1.84 & 6 & 0.12 & $0.87^{\mathrm{a}}$ \\
\hline Veneroida-Corbiculidae & 117 & 23.93 & 77 & 1.6 & $0.88^{\mathrm{a}}$ \\
\hline Tricladida-Planariidae & 8 & 1.64 & 450 & 9.3 & $-0.70^{b}$ \\
\hline Orthoptera-Caelifera & 5 & 1.02 & 0 & 0 & $1^{\mathrm{a}}$ \\
\hline Eggs (of themselves) & 4 & 0.82 & 0 & 0 & $1^{a}$ \\
\hline Hygrophila-Planorbidae & 0 & 0 & 6 & 0.12 & $-1^{b}$ \\
\hline Diptera-Tipulidae & 0 & 0 & 32 & 0.66 & $-1^{\mathrm{b}}$ \\
\hline Diptera-Chamaemyiidae & 0 & 0 & 119 & 2.5 & $-1^{\mathrm{b}}$ \\
\hline Ephemeroptera-Ephemeridae & 0 & 0 & 81 & 1.67 & $-1^{b}$ \\
\hline Total & 489 & 100 & 4,839 & 100 & \\
\hline
\end{tabular}

In Kavat Stream, west Iran ( $n=45$ stomach contents); macroinvertebrate species are expressed as the number of individuals per square meter in the study area.

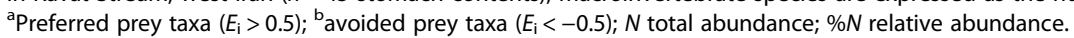

made up $11.58 \%$ of the total sampled populations (Table 4). The highest number of newts without stomach contents was caught on May. The accumulation curve for prey categories consumed by newt for species categories of benthic macroinvertebrates indicated an ascendant shape but with a tendency to achieve stabilization (Figure 2). This trend indicates that this study is based on a set of adequate sample size.

Absolute and relative values for abundance, frequency, and volume for all prey categories identified as food

Table 4 Frequency of empty stomachs and group characteristics of preys in the diet of $\mathbf{N}$. microspilotus

\begin{tabular}{ll}
\hline Description & Total \\
\hline Empty stomachs (\%) & 11.8 \\
Maximum no. of prey/individual & 45 \\
Average no. of prey & $9.9 \pm 8.4$ \\
Average number of prey species & $3.2 \pm 1.6$ \\
Aquatic prey (\%) & 99.63 \\
Terrestrial prey (\%) & 0.37 \\
Eggs (\%) & 0.91 \\
\hline
\end{tabular}

items from 45 stomach contents (including five empty stomachs) of $N$. microspilotus in Kavat Stream are shown in Table 5. Importance value $\left(I_{\mathrm{x}}\right)$ of Mycetophilidae (14.03\%), Baetidae (13.68\%), Corbiculidae (12.57\%), Gammaridae (10.8\%), and Lumbricidae (9.34\%) was also stone

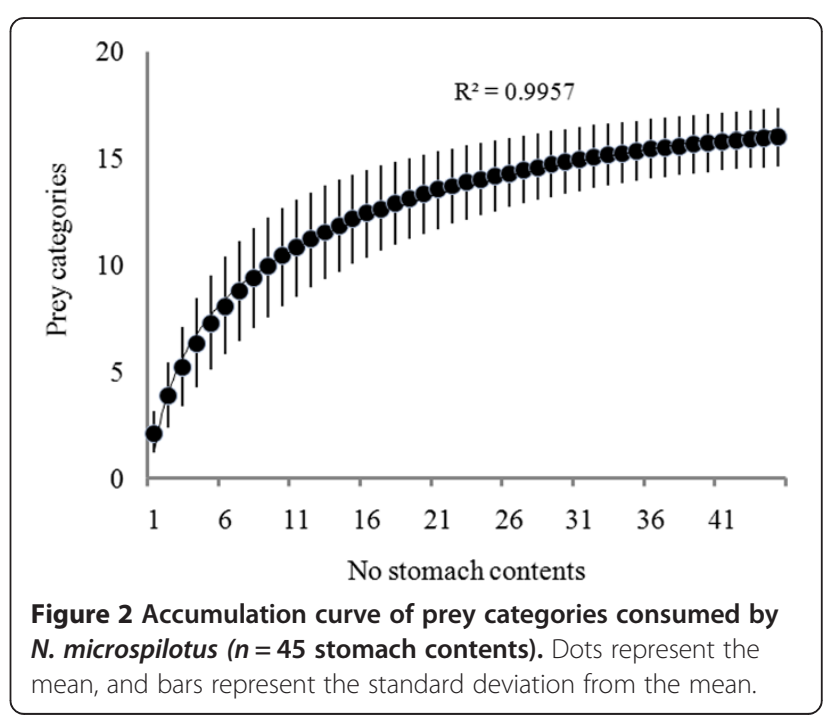


Table 5 Prey categories in the diet of $N$. microspilotus

\begin{tabular}{|c|c|c|c|c|c|c|c|}
\hline Prey category & $N$ & $\% N$ & $F$ & $\% F$ & $v$ & $\% V$ & $I_{\mathrm{x}}$ \\
\hline Annelida-Lumbricidae (aq-ad) & 22 & 4.5 & 11 & 8.4 & $1,121.67$ & 15.12 & 9.34 \\
\hline Amphipoda-Gammaridae (aq- ad) & 48 & 9.82 & 14 & 10.69 & 722.77 & 9.74 & 10.8 \\
\hline Diptera-Mycetophilidae (aq-I) & 120 & 24.54 & 18 & 13.74 & 282.85 & 3.83 & 14.03 \\
\hline Diptera-Cecidomyiidae (aq-l) & 13 & 2.66 & 8 & 6.11 & 512.1 & 6.90 & 5.22 \\
\hline Hemiptera-Veliidae (t-ad) & 4 & 0.82 & 3 & 2.29 & 105.11 & 1.42 & 1.51 \\
\hline Coleoptera-Dytiscidae (aq-I and ad) & 5 & 1.02 & 3 & 2.29 & 48.31 & 0.65 & 1.32 \\
\hline Coleoptera-Elmidae (t-ad) & 1 & 0.2 & 1 & 0.76 & 50.29 & 0.68 & 0.55 \\
\hline Ephemeroptera-Baetidae (aq-I) & 96 & 19.63 & 9 & 6.87 & $1,078.54$ & 14.54 & 13.68 \\
\hline Ephemeroptera-Heptageniidae (aq-l) & 9 & 1.84 & 4 & 3.05 & 684.56 & 9.23 & 4.71 \\
\hline Trichoptera-Hydropsychidae (aq-l) & 25 & 5.11 & 10 & 7.63 & 66.42 & 0.9 & 4.55 \\
\hline Hymenoptera-Formicidae (t-ad) & 3 & 0.61 & 2 & 1.53 & 55.47 & 0.75 & 0.96 \\
\hline Mesogastropoda-Bithynidae (aq-ad) & 9 & 1.84 & 5 & 3.82 & 276.35 & 3.73 & 3.13 \\
\hline Veneroida-Corbiculidae (aq-ad) & 117 & 23.93 & 4 & 3.05 & 795.43 & 10.72 & 12.57 \\
\hline Tricladida-Planariidae (aq-ad) & 8 & 1.64 & 3 & 2.29 & 462 & 6.23 & 3.39 \\
\hline Orthoptera-Caelifera (t-ad) & 5 & 1.02 & 3 & 2.29 & 65.12 & 0.88 & 1.4 \\
\hline Eggs (of themselves) & 4 & 0.82 & 4 & 0.818 & 2 & 1.53 & 0.90 \\
\hline Ston & 0 & 0 & 18 & 13.74 & 652.48 & 8.8 & 7.51 \\
\hline Plant remains & 0 & 0 & 13 & 9.92 & 241.1 & 3.25 & 4.39 \\
\hline Unidentified arthropod remains & 0 & 0 & 0 & 0 & 171.5 & 2.31 & 0.77 \\
\hline Total & 489 & & & & $7,417.54$ & & \\
\hline
\end{tabular}

In Kavat Stream, west Iran ( $\boldsymbol{n}=45$ stomach contents); $N$ abundance; $\% N$ relative abundance; $F$ frequency; $\% F$ relative frequency; $V$ volume $\left(m^{3}\right) ; \% V$ relative volume; $l_{x}$ importance index. $t$, terrestrial; aq, aquatic; ad, adult; l, larvae.

and plant materials. These families encompass about $82.42 \%$ of the total number of stomach contents, and about $17.38 \%$ of items that were extracted from their stomachs were from other categories (Table 5). The plant materials and small cobbles in the stomach of $N$. microspilotus were taken at both sampling occasions. Their eggs $(0.91 \%)$ were identified in the stomach contents of few newts in the last sampling occasion in late May (Table 4).

The feeding selectivity in $N$. microspilotus as expressed by the Ivlev's selectivity index $\left(E_{\mathrm{i}}\right)$ was computed (Table 3 ). The analysis of selectivity in feeding using Ivlev's index $\left(E_{\mathrm{i}}\right)$ showed that most of the prey taxa that appeared to be preferred were generally rare in the environment. The highest electivity was found for Caelifera and eggs $\left(E_{\mathrm{i}}=1\right)$, followed by Corbiculidae $\left(E_{\mathrm{i}}=0.88\right)$, Bithyniidae $\left(E_{\mathrm{i}}=0.87\right)$, and Baetidae $\left(E_{\mathrm{i}}=0.52\right)$. The lowest values were obtained for Planorbidae, Tipulidae, Chamaemyiidae, and Ephemeridae $\left(E_{\mathrm{i}}=-1\right)$, followed by Lumbricidae $\left(E_{\mathrm{i}}=-0.72\right)$, Planariidae $\left(E_{i}=-0.70\right)$, and Heptageniidae $\left(E_{i}=-0.58\right)$ (Table 3$)$.

\section{Discussion}

There is no available information concerning freshwater macroinvertebrate fauna in highland streams in western Iran. Relatively low diversity of benthic macrofauna in this study is not unusual and may be the consequence of low order of the stream. A wide range of $\alpha$-diversity has been reported for low order streams. Hawkeswood (2004) has reported only 14 species for the Murrumbidgee River, near Wagga Wagga, New South Wales, Australia. George et al. (2009) have reported 19 species in the Okpoka Creek in the Niger Delta. Also, Kazanc et al. (2003) has reported 21 species belonging to five classes from the channel entrance of Lake Koycegiz to the Mediterranean Sea, Turkey. Whereas macroinvertebrates are indicators of the water quality, the absence of polychaetes in the macroinvertebrate fauna from Kavat Stream may be attributed to the high level of water quality and lack of organic pollutants in this stream. This assertion is in agreement with the observation of many researchers (e.g., Mendez et al. 1998; Harlan 2008; Musale and Dattesh 2011; Omena et al. 2012) who reported that polychaetes were found in association with sites grossly polluted with organic matter, heavy metals, and petroleum hydrocarbons.

Benthic macroinvertebrate diversity in the two sampling occasions in April and May varies. In April, when water discharge was considerably high, 15 taxa were presented in the sampled quadrats. This increased to 17 taxa in May. The relative abundance of different taxa as expressed by the percentage of number also changed. In April, 
Lumbricidae (Aporrectodea rosea and Eiseniella tetraedra) and Mycetophilidae (Rhymosia sp.) comprised 75.15\% of the number of benthic macroinvertebrates, whereas in May, Gammaridae (Gammarus daiberi), Planariidae (Polycelis feline), Heptageniidae (Maccaffertium sp.), Hydropsychidae (Cheumatopsyche sp.), Baetidae (Baetis sp.), and Mycetophilidae (Rhymosia sp.) cover over $84.3 \%$ of the number of individuals. From April to May, $\alpha$-diversity as measured by Shannon-Wiener index of diversity of the benthic macroinvertebrates increased (0.69 to 0.90 ) but dominance as measured by the Simpson index reduced from 0.26 to 0.14 .

Analysis of regurgitated stomach contents including the empty stomachs (11.81\%) showed that on average $9.9 \pm 8.4$ benthic macroinvertebrate items are consumed by $N$. microspilotus. Compared to similar values for prey diversity in other Caudata, Covaciu-Marcov et al. (2010) have demonstrated that the Carpathian newt (Lissotriton montandoni) feeds on only 2.72 items. However, similar value for the great crested newt (Triturus cristatus) is 9.8 (David et al. 2009). The feeding intensity of the yellow-spotted newts in the first sampling occasion is lower (10.44) than the second sampling occasion (13.14). A low rate of the feeding intensity at the beginning of activity period has been reported in other species of amphibians (Hirai and Matsui 2000; Kovacs et al. 2007).
Such an increase in feeding intensity is believed to result from unfavorable weather conditions, mainly low temperatures, which affect both the predators and the prey (Guidali et al. 1999; Covaciu-Marcov et al. 2003). Similar to other species of newts such as Triturus cristatus (Kutrup et al. 2005 and Dobre et al. 2007), the yellowspotted mountain newts mainly feed on aquatic prey. In the present study, the average terrestrial item found in regurgitated stomach contents of the yellow-spotted newts comprise only $0.6 \%$ of the total prey items. The consumption of these terrestrial preys indicates that some individuals of $N$. microspilotus may leave the water and forage in the terrestrial environment; it is also possible that the terrestrial insects have drifted into the water by wind.

In the second sampling occasion in May, some newts consumed (1.81\%) their own eggs. N. microspilotus also consumed a high proportion of cobbles and plant materials. Although some stones may have been swallowed accidentally, it is possible that most of them were similar to soil-associated species such as caddis flies (Trichoptera) that were taken as food. The presence of caddis fly and stone fragments has been reported from the stomachs of another similar-sized salamander species, Salamander leurognathus (Martof and Scott 1957). Prey categories contained in the stomachs of 45 individuals indicate that

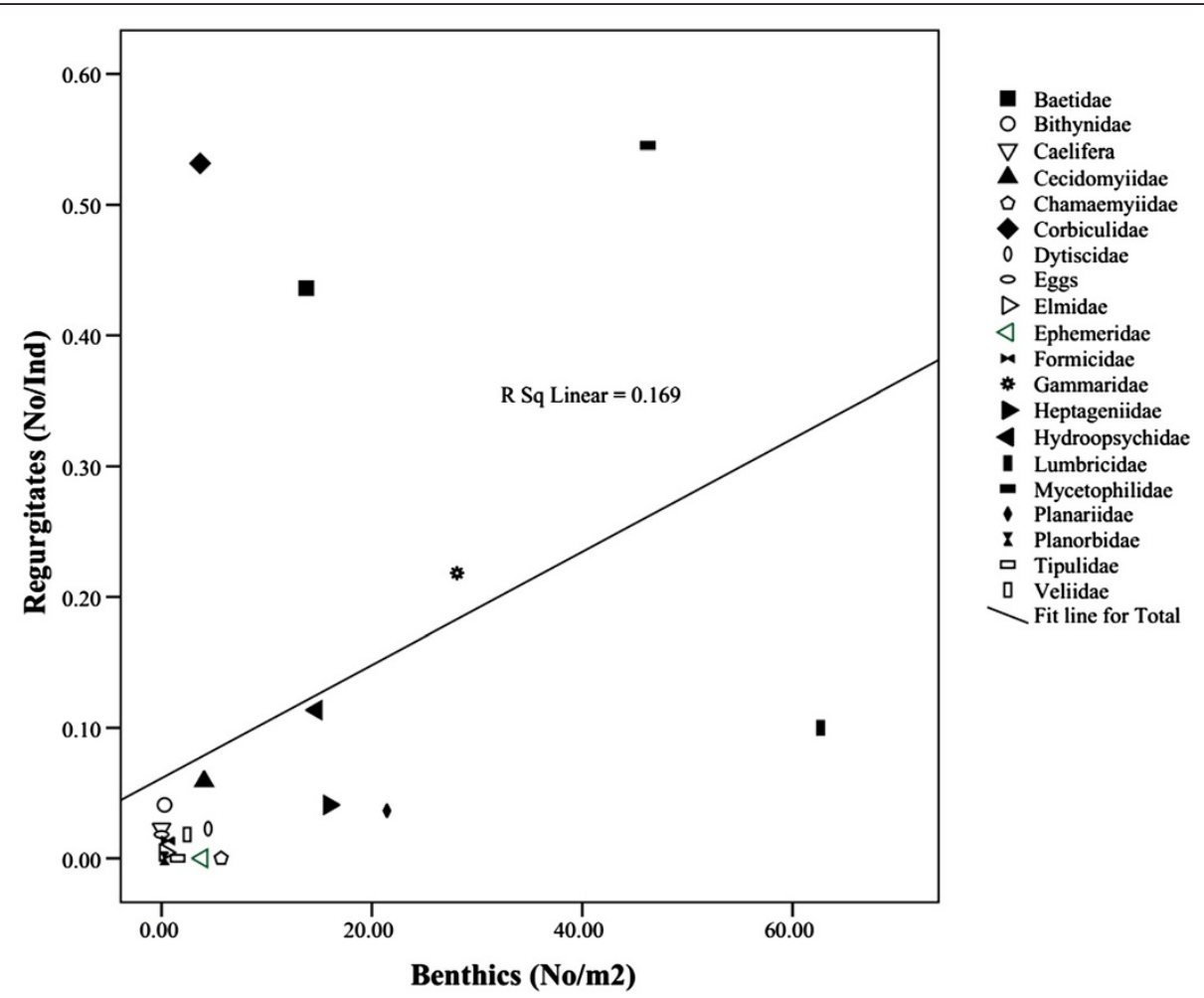

Figure 3 Overall relationship between the average number of benthic macroinvertebrates and the stomach contents of $N$. microspilotus. 
these mountain newts feed heavily on aquatic arthropods. However, in early spring when the water discharge is high, the newts avoid the main stream and occur in subterranean seepages and parallel shallow streams. At this time, they feed mainly on Corbiculidae (31.6\%), Lumbricidae (24.89\%), Cecidomyiidae (14.38\%), and Gammaridae (14.1\%). Later, when the water discharge is reduced, the newts enter into the main stream and feed mainly on Mycetophilidae (30.77\%), Baetidae (30.55\%), and Gammaridae (19.17\%).

In the present study, the 21 species of benthic macroinvertebrates belonging to 19 families, 13 orders, 6 classes, and 4 phyla were identified. Arthropoda with 14 families and 15 species and with a percent composition of $71.42 \%$ occurred most, followed by Mollusca with three families and three species and with a percent composition of 14.29\%. The remaining families (Lumbricidae and Planariidae) occurred with $9.5 \%$ and $4.8 \%$, respectively. The most abundant species groups including Lumbricidae, Mycetophilidae, Gammaridae, Planariidae, Heptageniidae, Hydropsychidae, and Baetidae, include $88.02 \%$ of benthic macroinvertebrate in April and May (Table 3). Similar taxa encompass $67.04 \%$ of the stomach contents of the yellowspotted mountain newt. Figure 3 demonstrates the overall relationship between relative abundance of benthic macroinvertebrate in Kavat Stream and regurgitated stomach contents of N. microspilotus sampled on two occasions in April and May 2012.

The feeding selectivity in $N$. microspilotus is expressed by Ivlev's selectivity index $\left(E_{\mathrm{i}}\right)$ indicating that there is an inconsistency among the abundance of benthic macroinvertebrates and the feeding items taken by $N$. microspilotus. For example, the most abundant prey taxa in the benthic community (Lumbricidae (27.20\%), Plananariidae (9.3\%), Hydropsychidae (6.38\%) show very low and negative Ivlev's index values of $-0.72,-0.70$, and -0.58 , respectively (Table 3 ). The analysis of selectivity in feeding using Ivlev's index showed that the prey taxa that appeared to be preferred $\left(E_{\mathrm{i}}>0.5\right)$ were generally rare in the environment. The low selectivity values obtained in the present study may be due to the lack of closely related species of Caudata in the study area (Sharifi and Assadian 2004). Competition among such species has been proposed as one of the principal mechanisms that can eventually lead to resource partitioning and species coexistence.

\section{Conclusions}

Comparison between benthic macroinvertebrates and those taken by the newt demonstrates that although high similarity (Sorenson index of 78.94\%) exists between the two communities, dominance of the items taken by the yellow-spotted newts as expressed by the Simpson index $(0.32)$ is higher than that of the benthic community $(0.20)$.
This indicates that the newt relies on fewer numbers of species with more balanced numbers of individuals of different species. Considering that N. microspilotus consumes the majority of the benthic macroinvertebrates (17 out of 21) reported in this study, it should be considered a nonspecialist or generalist predator. However, comparison between the relative abundance of the benthic macroinvertebrates and those taken by the newt (Figure 3) shows a coefficient of determination $r^{2}=0.17$. Feeding habits of the $45 \mathrm{~N}$. microspilotus have shown that the newts rely extensively on Mycetophilidae, Baetidae, Corbiculidae, Gammaridae, and Lumbricidae and other important food items for N. microspilotus.

\section{Competing interests}

The authors declare that they have no competing interests.

\section{Authors' contributions}

HF carried out all field work, collected benthic macroinvertebrate and extracted the stomach contents using gastric lavage, and drafted the manuscript. MS provided funding for the study, participated in few field studies, and finalized the manuscript. Both authors read and approved the final manuscript.

\section{Authors' information}

Hossein Farasat (first author) is a PhD student at the Department of Biology, Razi University, Kermanshah, Iran. He is studying various aspects of ecology and taxonomy of the yellow-spotted mountain newt under supervision of Mozafar Sharifi (second author). The present study is a part of the first author's PhD course.

\section{Acknowledgements}

We thank the organizations that supported this study, in particular, the Iran National Science Foundation (Contract code: 91057377) and Razi University that financially supported this study as a part of a PhD research project.

Received: 15 September 2013 Accepted: 27 August 2014

Received: 15 September 2013 Accepted: 27

References

Baloutch M, Kami G (1995) Amphibian of Iran. Tehran University Publications, Tehran (In Farsi)

Bouchard RW, Jr (2004) Guide to Aquatic Macroinvertebrates of the Upper Midwest. Water Resources Center University of Minnesota, St. Paul, MN

Caldart VM, lop S, Bertaso TRN, Cechin SZ (2012) Feeding ecology of Crossodactylus schmidti (Anura: Hylodidae) in Southern Brazil. Zool Stud 51:484-493

Cogalniceanu D, Aioanei F, Ciubuc C, Vadineanu A (1998) Food and feeding habits in a population of common spadefoot toads ( Pelobates fuscus) from an island in the lower Danube floodplain. Alytes 15:145-157

Cope ED (1862) On Neurergus crocatus from Iran and Iraq. Proc Acad Nat Sci Phil 1862:343

Covaciu-Marcov SD, Cupsa D, Cicort A, Naghi N, Vesea L (2003) Date despre spectrul trofic al unor populatii de Triturus alpestris din zona Muntelui Ses (jud. Bihor, România). Oltenia, Studii si Comunicari. Stiint Nat 19:171-176

Covaciu-Marcov SD, Cicort-Lucaciu AS, Diana CIS, ÉVA HK, Ferenti S (2010) Food composition of some low altitude Lissotriton montandoni (Amphibia, Caudata) populations from North-Western Romania. Arch Biol Sci 62:479-488

Colwell RK (2013) EstimateS: Statistical Estimation of Species Richness and Shared Species from Samples., Vers. 9. User's Guide and application published at: http://purl.oclc.org/estimates

David A, Cicort-Lucaciu AS, Roxin M, Pal A, Nagy-Zachari A (2009) Comparative trophic spectrum of two newt species, Triturus cristatus and Lissotriton vulgaris from Mehedinți County, Romania. Biol 3:133-137

Dobre F, Bucur DM, Mihut R, Birceanu M, Gale O (2007) Date asupra compozitiei hranei a unei populatii de Triturus cristatus (Laur. 1768) din Parcul National "Defileul Jiulul". România Biol 1:23-28 
Dunham AE (1983) Realized niche overlap, resource abundance and intensity of interspecific competition. In: Huey RB, Er P, Schoener TW (ed) Lizard Ecology: Studies of a Model Organism. Harvard Univ, Cambridge, MA, pp 261-280

George ADI, Abowei JFN, Daka ER (2009) Benthic macroinvertebrate fauna and physico-chemical parameters in Okpoka creek sediments, Niger Delta, Nigeria. Int J Anim Vet Advs 1:59-65

Guidali F, Scali S, Carettoni A, Fontaneto D (1999) Feeding habits, niche breadth and seasonal dietary shift of Rana dalmatina in northern Italy. Current studies in herpetology. Soc Eur Herpetol :161-166

Harlan KD (2008) The use of polychaetes (Annelida) as indicator species of marine pollution: a review. Rev Biol Trop 56:11-38

Hawkeswood TJ (2004) A brief investigation into the benthic macroinvertebrate fauna of one section of the Murrumbidgee River, New South Wales, Australia, using kick, net and surber sampling methods. Calodema 2:1-5

Hirai T, Matsui M (2000) Feeding habits of the Japanese tree frog, Hyla japonica, in the reproductive season. Zool Sci 17:977-982

Ivlev VS (1961) Experimental ecology of the feeding of fishes. Yale, New Haven, Connecticut

Kerim ÜEK, Ahmet M (2007) Food composition of the marsh frog, Rana ridibunda Pallas, 1771, in Thrace. Turk J Zool 31:83-90

Kazanc N, Oguzkurt D, Girgin S, Dugel M (2003) Distribution of benthic macroinvertebrates in relation to physic-chemical properties in the Koycegiz-Dalyan estuarine channel system (Mediterranean Sea, Turkey). Indian J Mar Sci 32:141-146

Kovacs EH, Sas I, Covaciu-Marcov SD, Hartel T, Cupsa D, Groza M (2007) Seasonal variation in the diet of a population of Hyla arborea from Romania. Amphibia Reptilia 28:485-491

Kutrup B, Cakir E, Yilmaz N (2005) Food of the banded newt, Triturus vittatus ophryticus (Berthold, 1846) at different sites in Trabzon. Turk J Zool 29:83-89

Maerz JC, Myers EM, Adams DC (2006) Trophic polymorphism in a terrestrial salamander. Evol Ecol Res 8:23-35

Martof B, Scott D (1957) The food of the Salamander Leurognathus. Ecology 38:494-501

Mendez N, Flos J, Romero J (1998) Littoral soft-bottom polychaete communities in pollution gradient in front of Barcelona (Western Mediterranean, Spain) Bull Mar Sci 63:167-178

Musale AS, Dattesh VD (2011) Distribution and abundance of macrobenthic polychaetes along the South Indian coast. Environ Monit Assess 178:423-436

Nesterov PV (1916) Trois formes nouvelles d'Amphibiens (Urodela) du Kurdistan. Annu Mus Zool Acad 21:1-30 [in Russian]

Omena EP, Lavrado HP, Paranhos R, Silva TA (2012) Spatial distribution of intertidal sandy beach polychaeta along an estuarine and morphodynamic gradient in a eutrophic tropical bay. Mar Pollut Bull 64(9):861-873

Parker D, Consulting AT (2012) Identification Key to the Orders of Saskatchewan Aquatic Insect Larvae and Adults. Available from http://www.aquatax.ca/ TaxaKeyImages /SKAquaticlnsectOrders-Ver-9Mar.pdf. Accessed 15 April 2013

Santos JWA, Damasceno RP, Rocha PL (2003) Feeding habits of the frog Pleurodema diplolistris (Anura, Leptodactylidae) in Quaternary sand dunes of the middle Rio Sao Francisco, Bahia, Brazil. Phyllomedusa 2:83-92

Schmidtler JJ, Schmidtler JF (1975) Untersuchujngen an westpersischen Bergbachmolchen der Gattung Neurergus (Caudata, Salamandridae). Salamandra 1:84-98

Schmidt KP (1952) Diagnoses of new amphibians and reptiles from Iran. Nat Hist Miscellanea 93:1-2

Serdar DM, Rizvan TM (2004) Analysis of the stomach contents of the Mertensiella Iuschani (Steindachner, 1891). Asiat Herpetol Res 10:164-167

Sharifi M, Assadian S (2004) Distribution and conservation status of Neurergus microspilotus (Caudata: Salamandridae) in western Iran. Asiat Herpetol Res 10:224-229

Sharifi M, Vaissi S (2014) Captive breeding and trial reintroduction of the endangered yellow-spotted mountain newt Neurergus microspilotus in Western Iran. 23:159-166. Doi: 10.3354/esr00552

Sreelatha KS, Natarajan P, Ritakumari SD (1990) Studies on the food and feeding behaviour of Bufo melanostictus. J Eco Biol 2:232-233
Thyssen PJ (2010) Keys for Identification of Immature Insects. Available from http://www.springer.com/cda/content/document/cda_downloaddocument/ 9781402096839 -c2.pdf?SGWID =0-0-45-1118144-p173877432. Accessed 15 April 2013

Toshiaki H (2002) Ontogenetic change in the diet of the pond frog, Rana nigromaculata. Ecol Res 17:639-644

doi:10.1186/s40555-014-0061-z

Cite this article as: Farasat and Sharifi: Food habit of the endangered yellow-spotted newt Neurergus microspilotus (Caudata, Salamandridae) in Kavat Stream, western Iran. Zoological Studies 2014 53:61.

\section{Submit your manuscript to a SpringerOpen ${ }^{\odot}$ journal and benefit from:}

- Convenient online submission

- Rigorous peer review

- Immediate publication on acceptance

- Open access: articles freely available online

- High visibility within the field

- Retaining the copyright to your article

Submit your next manuscript at $\gg$ springeropen.com 